\title{
SYNTHESIS, CHARACTERIZATION OF ANTIMICROBIAL ACTIVITY OF 22'DICHLOROHYDROBENZOIN
}

\author{
THANUJA B ${ }^{1 *}$, CHARLES KANAGAM ${ }^{2}$ \\ ${ }^{1}$ Department of Chemistry, Sri Sairam Engineering College, Tambaram, Chennai, Tamil Nadu, India. ${ }^{2}$ Department of Chemistry, Presidency College, \\ Chennai, Tamil Nadu, India. Email: thanuja.che@sairam.edu.in \\ Received: 09 July 2018. Revised and Accepted: 03 August 2018
}

\section{ABSTRACT}

Objective: The objective of this work to evaluate the antimicrobial activities of synthesized 22'dichlorohydrobenzoin (22'CD) a new organic crystal.

Methods: $22^{\prime} \mathrm{CD}$ a new organic crystal was grown by vapor diffusion method. Single crystals of $22^{\prime} \mathrm{CD}$ have been subjected to X-ray diffraction analysis to estimate the lattice parameters and the space group. The molecular structure was confirmed using Fourier transform infrared and nuclear magnetic resonance (NMR) spectral analyses. Optical behavior and thermal stability of the crystal were determined using UV-Vis spectroscopy and thermogravimetry-differential thermal analysis curves. In the present study, antimicrobial activity of 22'CD was evaluated against Escherichia coli and Bacillus subtilis was evaluated by agar well diffusion method.

Results: Antibacterial activity of $22^{\prime} \mathrm{CD}$ was analyzed with ciprofloxacin and miconazole standard and tested against E. coli, Pseudomonas aeruginosa, Salmonella paratyphi, Klebsiella pneumonia's, Staphylococcus aureus, Streptococcus progenies, and B. subtilis.

Conclusion: The 22' $\mathrm{CD}$ was found to be effective against E. coli and B. subtitles.

Keywords: Synthesis, Characterization, Single X-ray diffraction, Antimicrobial activity, Agar well diffusion method.

(c) 2018 The Authors. Published by Innovare Academic Sciences Pvt Ltd. This is an open access article under the CC BY license (http://creativecommons. org/licenses/by/4. 0/) DOI: http://dx.doi.org/10.22159/ajpcr.2018.v11i12.28360

\section{INTRODUCTION}

Even though pharmacological industries have produced a number of new antibiotics in the last three decades, resistance to these drugs by microorganisms has increased. In general, bacteria have the genetic ability to transmit and acquire resistance to drugs, which are utilized as therapeutic agents. Such a fact is cause for concern, because of the number of patients in hospitals who have suppressed immunity, and due to new bacterial strains which are multi-resistant. Consequently, new infections can occur in hospitals resulting in high mortality. The problem of microbial resistance is growing, and the outlook for the use of antimicrobial drugs in the future is still uncertain [1-6].

Therefore, actions must be taken to reduce this problem, for example, to control the use of antibiotic, to develop research to better understand the genetic mechanisms of resistance, and to continue studies to develop new drugs, either synthetic or natural. The ultimate goal is to offer appropriate and efficient antimicrobial drugs to the patient.

Compounds having diol group are reported to exhibit a broad spectrum of biological activity such as antibacterial [7-9] and antifungal [10,11]. No diol compounds yet been synthesised with two electron withdrawing chloro groups as a substituents to our best knowledge. The structure of pure compound was characterized on the basis of IR, mass and ${ }^{1} \mathrm{H}$ nuclear magnetic resonance (NMR), and ${ }^{13} \mathrm{C}$ NMR spectral analysis and single crystal X-ray diffraction (XRD) studies. The synthesized compound was evaluated for antimicrobial activity using agar well diffusion method.

\section{METHODS}

Synthesis and purification of $22^{\prime}$ dichlorohydro benzoin [22' $\left.\mathrm{CD}\right]$ The starting material, for the synthesis of $22^{\prime} \mathrm{CD}$, which was synthesized by benzoin condensation. About $4 \mathrm{~g}$ of KCN dissolved in $75 \mathrm{cc}$ of water in a $1 \mathrm{~L}$ flask. $14 \mathrm{~g}$ of 2-chlorobenzaldehyde and $75 \mathrm{cc}$ of $95 \%$ ethanol were added into the flask. The mixture formed into a solution at the boiling temperature and was refluxed for $1 \frac{1}{2} \mathrm{~h}$. Steam was then passed through the solution until all the alcohol and nearly all the unreacted aldehydes were removed. The condensed water was decanted from the product and later set aside for crystallization. The product was then pressed as free as possible from oily material on a suction funnel and washed with cold alcohol. In this way, about 14 $\mathrm{g}$ (yield was $60 \%$ ) of crude product was obtained. It is noteworthy that this product is exceptionally easily oxidized to $22^{\prime} \mathrm{CD}$ when comes into contact with air [12]. $1.5 \mathrm{~g}$ of 2, 2' - dichlorobenzil was diluted in $15 \mathrm{~mL}$ of absolute ethanol and taken in Erlenmeyer flask. It was gently warmed with swirling. $300 \mathrm{mg}$ of sodium borohydride was added in small portions over 3-4 min. Flask was swirled or stirred continuously for another $15 \mathrm{~min} .30 \mathrm{~mL}$ of water was added cautiously and flask was cooled in an ice bath and constantly stirred. Concentrated $\mathrm{HCl}$ was added in dropwise and stirred until foaming ceases. To this, 10 $\mathrm{mL}$ of water was added and stirred continuously for 10-15 min. The precipitate was collected using suction funnel. The precipitate was washed with $25 \mathrm{~mL}$ of cold water and allowed to dry in air. The crude product was recrystallized from acetone-petroleum ether by vapor diffusion method (Scheme 1).

The structure of the title compound was characterized by mass, IR, and NMR spectra. Mass spectrum was recorded using JEOL GC mate mass spectrometer. The infrared spectrum was recorded using Perkin Elmer spectrometer and alpha spectrometer in the frequency range of $4000-450 / \mathrm{cm}$, using $\mathrm{KBr}$ pellet method. NMR spectrum was recorded using BRUKER $500 \mathrm{MHz}$ AVANCE III instrument using CDCl3, DMSO-d6, acetone-d6 and MeOD as solvent, with TMS as an internal standard.

\section{Antibacterial activity of $22^{\prime} \mathbf{C D}$}

The antibacterial activity of $22^{\prime} \mathrm{CD}$ was determined using the hole-inplate bioassay procedure. The pure cultures of the microorganisms were inoculated onto Muller-Hilton nutrient broth incubated at temperature 
of $37^{\circ} \mathrm{C}$ for $24 \mathrm{~h}$ [13]. Using a sterile cork borer of $5 \mathrm{~mm}$ diameter, three holes were made into the Petri dishes seeded with bacterial culture. The various concentrations of the synthesized compounds were inoculated in the wells prepared on the agar plates. The plates were incubated at temperature of $37^{\circ} \mathrm{C}$ for $18 \mathrm{~h}$. Staphylococcus aureus (ATCC 25923), Escherichia coli 0157:H7 (PSSCMI 0032), Salmonella paratyphi (PSSCMI 0034), and Bacillus subtilis were used as the test microorganisms. All bacterial cultures were maintained on nutrient

Table 1: Mass spectral fragmentation peaks for 22'CD

\begin{tabular}{ll}
\hline Peaks & Fragmentation \\
\hline 282.96 & $\mathrm{M}^{+}$ \\
247.2 & $\mathrm{M}^{+}-\mathrm{Cl}$ \\
177.5 & $\mathrm{M}^{+}-\mathrm{CONH}$ \\
164.4 & {$\left[\mathrm{C}_{6} \mathrm{H}_{4} \mathrm{Cl}-\mathrm{OC}-\mathrm{CO}^{-}\right]^{+}$} \\
140.4 & {$\left[\mathrm{C}_{6} \mathrm{H}_{4} \mathrm{Cl}-\mathrm{CH}(\mathrm{OH})\right]^{+}$} \\
\hline
\end{tabular}

22'CD: 22'dichlorohydrobenzoin

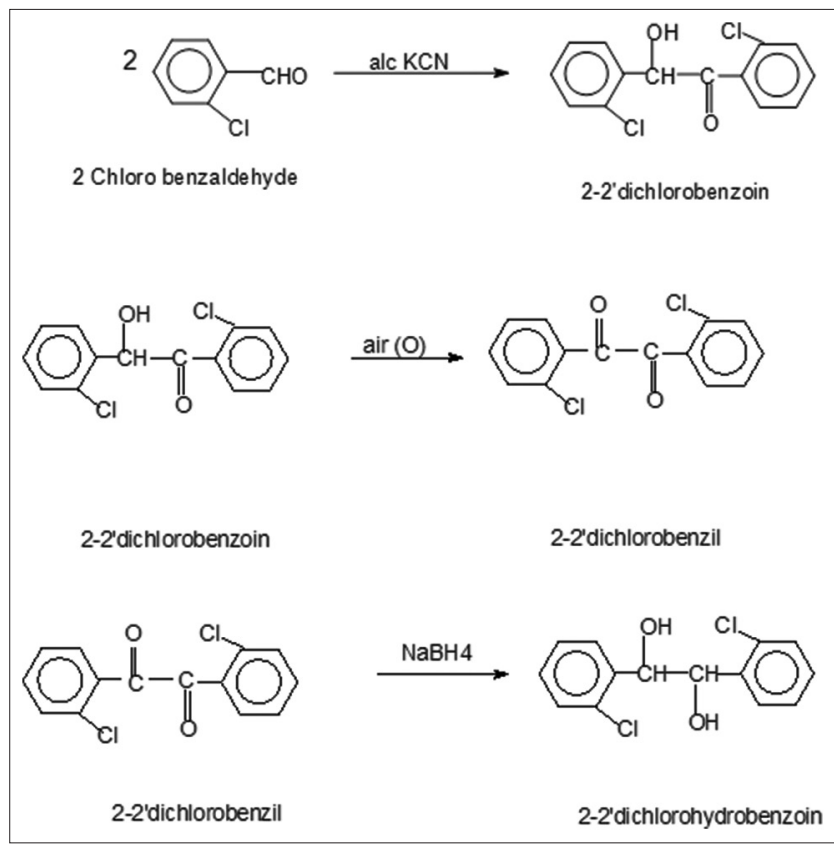

Scheme 1: Schematic representation of 22 'dichlorohydrobenzoin agar slants at temperature of $4^{\circ} \mathrm{C}$ and subcultured onto nutrient agar broth for $24 \mathrm{~h}$ before testing [14].

\section{Antifungal activity of $22^{\prime} \mathrm{CD}$}

Various concentrations of synthesized compounds were powered into the wells and examined against C. albicans and Aspergillus niger. Holes were made into the Petri dishes containing inoculated medium. The diameter of the clear zone around the wells (inhibition diameter) was measured at the end of the incubation period. The samples that presented high mean diameter were subjected to minimum inhibitory concentration analysis as described above. Three $22^{\prime} \mathrm{CD}$ doses in wells per plate against a single microorganism were used [15]

\section{Antimicrobial assay isolation and maintenance of cultures}

E. coli, Pseudomonas aeruginosa, S. paratyphi, Klebsiella pneumoniae, S. aureus, Streptococcus pyogenes, and B. subtilis were extracted from foodstuffs by serial dilution agar plate method. In this method, serial dilutions of samples obtained from foodstuffs were prepared, and aliquots from each dilution were added to the plates containing nutrient agar to allow the growth of microbes. All the bacterial isolates were identified by cultural, morphological biochemical characteristics (Gram and endospore staining). The plates were kept in an incubator at $37^{\circ} \mathrm{C}$. The slants were prepared from the pure cultures obtained and kept in the refrigerator at $4^{\circ} \mathrm{C}$ for further use.

\section{Standardization of inoculum}

The microbial inoculum was standardized at 0.5 McFarland. In microbiology, McFarland standards are used as a reference to adjust the turbidity of bacterial suspensions so that the number of bacteria will be within a given range. Original McFarland standards were made by mixing specified amounts of barium chloride and sulfuric acid together. Mixing the two compounds forms a barium sulfate precipitate, which causes turbidity in the solution. A 0.5 McFarland standard is prepared by mixing $0.05 \mathrm{ml}$ of $1.175 \%$ barium chloride dihydrate $(\mathrm{BaCl} 2 \cdot 2 \mathrm{H} 2 \mathrm{O})$, with $9.95 \mathrm{ml}$ of $1 \%$ sulfuric acid (H2SO4). The standard could be compared visually to a suspension of bacteria in sterile saline or nutrient broth [16].

\section{RESULTS AND DISCUSSION}

Mass spectral analysis of 22'CD

Mass spectral data and elemental analysis were in good agreement with the assigned formula (Table 1 and Fig. 1).

Fourier transform infrared (FTIR) spectral analysis of 22'CD

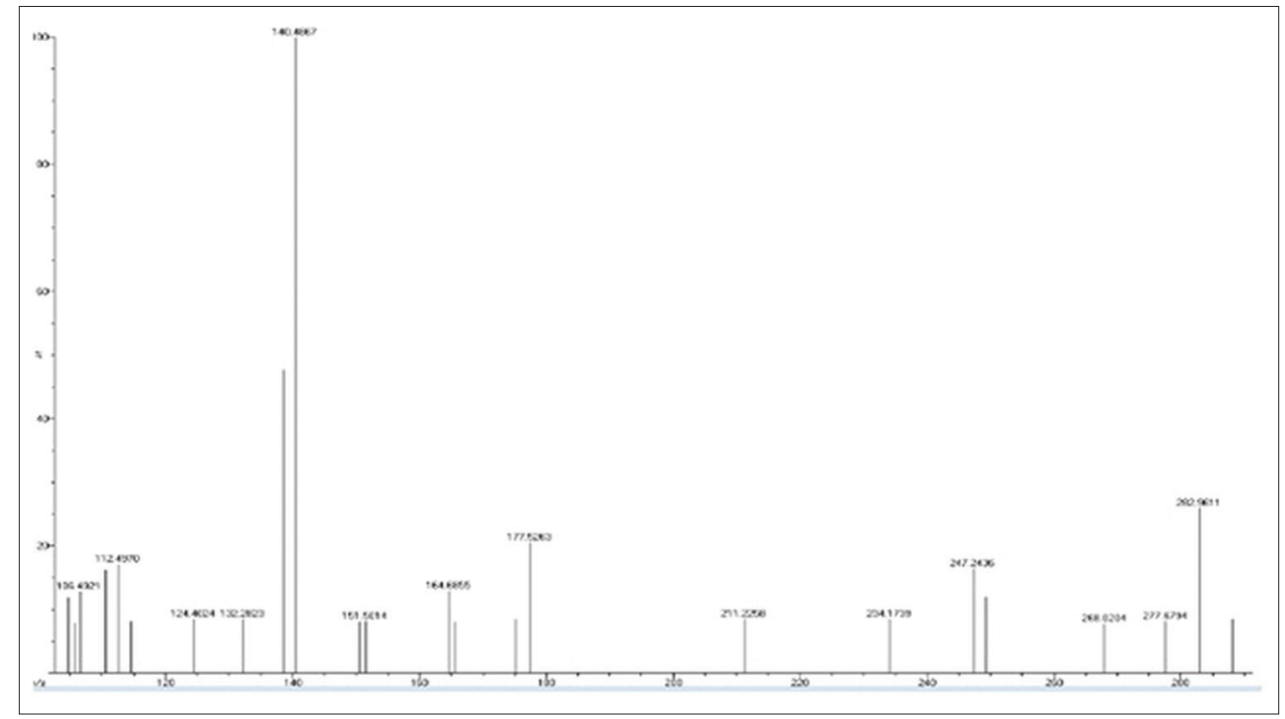

Fig. 1: Mass spectra of 22'dichlorohydrobenzoin 
In FTIR spectrum of the $22^{\prime} \mathrm{CD}$, the $-\mathrm{OH}$ stretching modes were found at $3332 / \mathrm{cm}$. The bands around $3000 / \mathrm{cm}$ in FTIR were assigned to the aromatic $\mathrm{C}-\mathrm{H}$ stretching modes. The aliphatic $-\mathrm{CH}$ stretching vibration was assigned to the band at $2925 / \mathrm{cm}$ in FTIR with weak intensity (Table 2). The aromatic $\mathrm{C}=\mathrm{C}$ symmetric stretching vibrations appear at $1439 / \mathrm{cm}$ as a strong intensity. The $-\mathrm{OH}$ out of plane deformation was observed as strong band around $1007 / \mathrm{cm}$. The band at $741 / \mathrm{cm}$ in FTIR indicates the presence of disubstituted benzene ring (Fig. 2).

\section{FT NMR spectral analysis of 22'CD}

The ${ }^{1} \mathrm{H}$ NMR and ${ }^{13} \mathrm{C}$ NMR spectral signals of the 22 ' $\mathrm{CD}$ were observed (Fig. 3a and b). The corresponding datum was presented in Table 3. The spectra exhibit a multiplet at $6.8-7.5 \mathrm{ppm}$ for the hydrogens of the aromatic rings hydrogen. The $-\mathrm{CHOH}$ hydrogen leads to a broad singlet of intensity equivalent to two hydrogens at $3 \mathrm{ppm}$. The spectra show doublet with an integration equivalent to two hydrogens at 5.8-5.9 ppm corresponding to the hydrogen of the $-\mathrm{CH}-\mathrm{CH}$ group (the signal appears as a doublet of doublet in expanded spectra).

In the ${ }^{13} \mathrm{C}$ NMR, aliphatic carbon appears in the range of 60-80 ppm and aromatic carbon atoms appear in the range of 127-137 ppm.

\section{Agar well diffusion method}

For determination of antimicrobial activity of $22^{\prime} \mathrm{CD}$, different bacterial and fungal strains were used by agar ditch method. The pathogenic cultures were swabbed separately in each air-dried preincubated nutrient agar and Sabouraud dextrose agar plates with the help of sterile cotton swabs. Ditches were prepared in agar plates with the help of surface sterilized borer. After boring, the test drug of different concentrations was added separately to the ditches (50 $\mu$ l) [17-20].

The commercial available ciprofloxacin Ranbaxy Laboratory Limited, New Delhi, was used for comparison study. The antibiotic ciprofloxacin and fungicidal agent miconazole were prepared and the concentrations $(50 \mu \mathrm{g} / \mathrm{ml})$ were impregnated into ditches in agar medium. The plates were incubated at $37^{\circ} \mathrm{C}$. Controls were maintained. After $24 \mathrm{~h}$ diameter of clear zone produced around the ditches were measured to the nearest $\mathrm{mm}$ with the help of the micro scales.

Antibacterial activity of 22'CD was tested using agar well diffusion method. $200 \mu \mathrm{l}$ of bacteria was aseptically introduced and spread using cotton swabs on the surface of gelled sterile Muller-Hilton

Table 2: Vibrational assignments of the 22'CD

\begin{tabular}{ll}
\hline $\begin{array}{l}\text { FTIR for 22'CD } \\
\text { (wavenumber } \mathbf{~ c m}^{-1} \text { ) }\end{array}$ & Band assignments \\
\hline $3332 / \mathrm{cm}[\mathrm{vs}]$ & -OH stretching \\
$3070 / \mathrm{cm}$ & Aromatic C-H stretching \\
$2925 / \mathrm{cm}[\mathrm{w}]$ & Aliphatic C-H stretching \\
$1439 / \mathrm{cm} \mathrm{[s]}$ & Aromatic sym C=C stretching \\
$1007 / \mathrm{cm}$ & -OH out of plane deformation \\
$741 / \mathrm{cm}$ & Disubstituted benzene ring deformation \\
\hline
\end{tabular}

22'CD: 22'dichlorohydrobenzoin, FTIR: Fourier transform infrared, w: Weak;

vw: Very weak, m: Medium, s: Strong, vs: Very strong

Table 3: The chemical shift in ${ }^{1} \mathrm{H}$ NMR and ${ }^{13} \mathrm{C}$ NMR spectrum of 22'CD

\begin{tabular}{lll}
\hline Spectrum & Signal (ppm) & Group identification \\
\hline${ }^{1} \mathrm{H} \mathrm{NMR}$ & $2.0 \mathrm{ppm}$ & $-\mathrm{CHOH}$ \\
& $5.8-5.9 \mathrm{ppm}$ & $\mathrm{CH}-\mathrm{CH}$ \\
& $6.8-7.5 \mathrm{ppm}(\mathrm{multiplet})$ & Aromatic protons \\
${ }^{13} \mathrm{C} \mathrm{NMR}$ & 60 and $80 \mathrm{ppm}$ & Aliphatic carbon atoms \\
& $127-137 \mathrm{ppm}$ & Aromatic carbon atoms \\
\hline
\end{tabular}

22'CD: 22'dichlorohydrobenzoin, NMR: Nuclear magnetic resonance agar plates. A well of about $6.0 \mathrm{~mm}$ diameter with sterile cock borer was aseptically punched on each agar plate. 22 'CD in different three concentrations was introduced into the wells in the plates. A negative control well was too made with $50 \mu \mathrm{l}$ of the sterile distilled water. A positive control was made by placing antibiotic disc (ciprofloxacin) on agar plate. Plates were kept in laminar flow for $30 \mathrm{~min}$ for prediffusion of $22^{\prime} \mathrm{CD}$ to occur and then incubated at $37^{\circ} \mathrm{C}$ for $24 \mathrm{~h}$. Resulting zone of inhibition was measured using a Hi-Media zone scale.

The antibacterial activity of 22' $\mathrm{CD}$ was found to be effective against both E. coli with zone of inhibition of $10 \mathrm{~mm}$ (Table 4) and B. subtilis with zone of inhibition ranging between 8 and $10 \mathrm{~mm}$ (Table 5). The 22' CD lower concentration was ineffective against both the test organisms (Fig. 4).

The inhibition zone formation of 22' $\mathrm{CD}$ was compared with the standard antibiotic miconazole (Table 6). The zone of inhibition at $100 \mu \mathrm{g} / \mathrm{ml}$ concentration was maximum. However, the high dose used presented significant activity against $C$. albicans and A. niger. From these results, it was observed that 22 'CD bioactivity varied with the concentrations used (Fig. 5).

\section{CONCLUSION}

Antimicrobial studies of 22'CD showed higher antimicrobial activity against Gram-positive bacteria compared to Gram-negative bacteria.

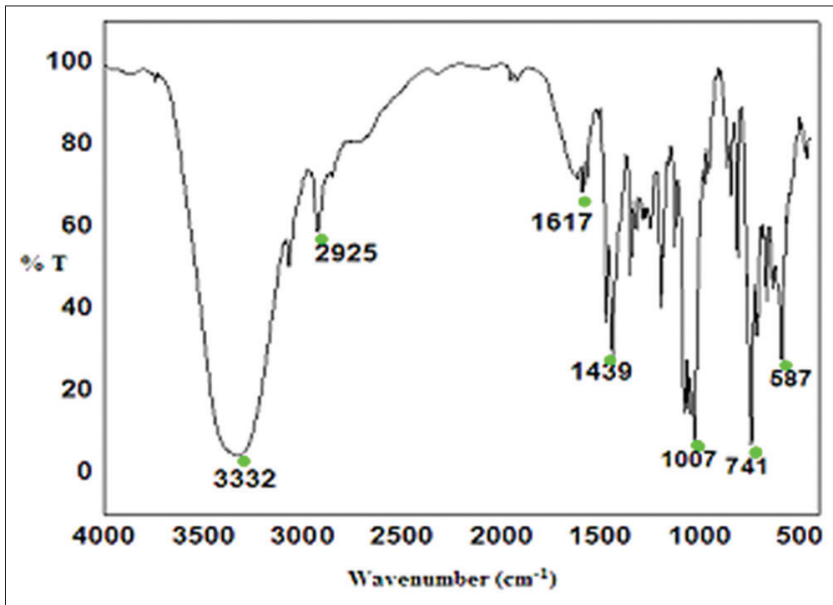

Fig 2: Infrared spectra of 22'dichlorohydrobenzoin in $\mathrm{KBr}$

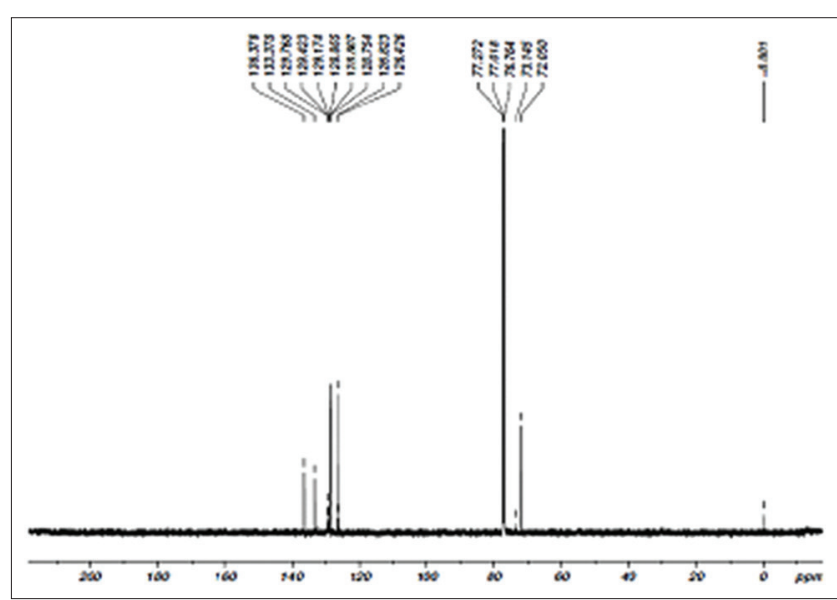

Fig. 3: [b] 13C nuclear magnetic resonance of 22'dichlorohydrobenzoin 
Table 4: Antimicrobial activity on Gram -ve microorganism

\begin{tabular}{|c|c|c|c|c|}
\hline \multirow{2}{*}{$\begin{array}{l}\text { Antimicrobial agent } \\
\text { Concentration }\end{array}$} & \multicolumn{4}{|c|}{ Inhibition zones in diameter (mm) } \\
\hline & Escherichia coli & Pseudomonas aeruginosa & Salmonella paratyphi & Klebsiella pneumoniae \\
\hline $22^{\prime} \mathrm{CD}(25 \mu \mathrm{g} / \mathrm{ml})$ & 6 & 7 & 7 & 7 \\
\hline $22^{\prime} \mathrm{CD}(100 \mu \mathrm{g} / \mathrm{ml})$ & 10 & 12 & 10 & 9 \\
\hline Standard $(50 \mu \mathrm{g} / \mathrm{ml})$ & 9 & 10 & 8 & 8 \\
\hline
\end{tabular}

22'CD: 22'dichlorohydrobenzoin

Table 5: Antimicrobial activity on Gram+ve microorganism

\begin{tabular}{llll}
\hline Antimicrobial agent concentration & \multicolumn{2}{l}{ Inhibition zones in diameter $(\mathbf{m m})$} & Streptococcus pyogenes \\
\cline { 2 - 4 } & Staphylococcus aureus & 6 & Bacillus subtilis \\
\hline $22^{\prime} \mathrm{CD}(25 \mu \mathrm{g} / \mathrm{ml})$ & 5 & 7 & 6 \\
$22^{\prime} \mathrm{CD}(50 \mu \mathrm{g} / \mathrm{ml})$ & 5 & 10 & 8 \\
$22^{\prime} \mathrm{CD}(100 \mu \mathrm{g} / \mathrm{ml})$ & 6 & 10 \\
Standard $(50 \mu \mathrm{g} / \mathrm{ml})$ & 8 & 10 \\
\hline
\end{tabular}

22'CD: 22'dichlorohydrobenzoin

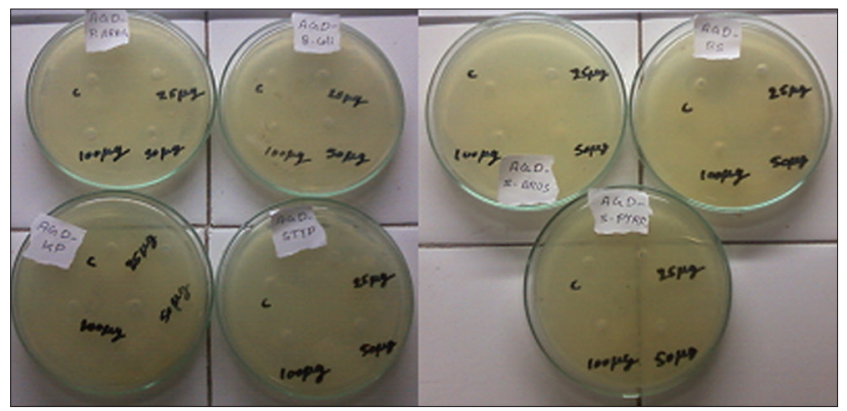

Fig. 4: Antimicrobial activity on Gram +ve and -ve microorganism

Table 6: Antimicrobial activity on fungi

\begin{tabular}{llll}
\hline \multicolumn{1}{l}{ Antimicrobial agent } & & \multicolumn{2}{c}{ Inhibition zones in diameter $(\mathbf{m m})$} \\
\cline { 1 - 1 } Concentration & & Candida albicans & Aspergillus niger \\
\hline 22'CD $(25 \mu \mathrm{g} / \mathrm{ml})$ & & 3 & 3 \\
22'CD $(50 \mu \mathrm{g} / \mathrm{ml})$ & & 4 \\
22'CD $(100 \mu \mathrm{g} / \mathrm{ml})$ & 6 & 7 \\
Standard $(50 \mu \mathrm{g} / \mathrm{ml})$ & 8 & 8 \\
\hline
\end{tabular}

22'CD: 22'dichlorohydrobenzoin

\section{AUTHORS' CONTRIBUTION}

Concept and writing of the article Thanuja B and review of the article Charles Kanagam.

\section{CONFLICTS OF INTEREST}

The authors report no conflicts of interest.

\section{REFERENCES}

1. Andrews JM. Determination of minimum inhibitory concentrations. J Antimicrob Chemother 2001;48 Suppl 1:5-16.

2. Darout I, Cristy A, Skaug N, Egeberg P. Identification and quantification of some potential antimicrobial anionic components in miswak extract. Ind J Pharm 2000;32:11-4.

3. El-Astal ZY, Ashour AA and Kerrit A. Antimicrobial activity of some medicinal plant extracts. West Afr J Pharm Drug Res 2003;19:16-21.

4. Elizabeth KM. Antimicrobial activity of Alliumsatirum on some pathogenic bacteria. Indian J Microbiol 2001;4:321-3.

5. Hoque MD, Bari ML, Inatsu Y, Juneja VK, Kawamoto S. Antibacterial activity of guava (Psidiumguajava) and Neem (Azadirachtaindica) extracts against foodborne pathogens and spoilage bacteria. Foodborne Pathog Dis 2007;4:481-8.

6. Johnson TR, Christine LC. Laboratory Experiments in Microbiology.

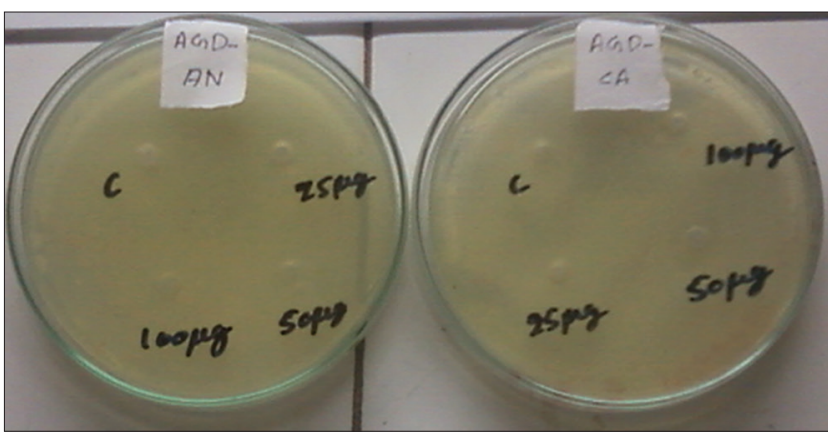

Fig. 5: Antimicrobial activity on fungi

Brief edition. 2nd ed. California, US: The Benjamin, Cummings Publishing Co: 1989

7. Sakiyan I, Loğoğlu E, Arslan S, Sari N, Sakiyan N. Antimicrobial activities of $\mathrm{N}$-(2-hydroxy-1-naphthalidene)-amino acid(glycine, alanine, phenylalanine, histidine, tryptophane) schiff bases and their manganese(III) complexes. Biometals 2004;17:115-20.

8. Chohan ZH, Arif M, Shafiq Z, Yaqub M, Supuran CT. In vitro antibacterial, antifungal and cytotoxic activity of some isonicotinoyl hydrazide schiff's bases and their cobalt(II), Copper(II), nickel(II) and Zinc(II) complexes. J Enzyme Inhib Med Chem 2006;21:95-103.

9. Wang YP, Xiao YN, Zhang CX, and Wang RM. Studies on the interaction of DNA and water-soluble polymer-supported Schiff base complex. J Macromol Sci Part A 2001;38:1099-104.

10. Pandeya SN, Sriram D, Nath G, De C, Lecq E. Synthesis, antibacterial, antifungal and anti-HIV activities of schiff and mannich bases derived from Isatin derivatives and N-[4-(4'chlorophenyl)thiazol-2-yl]. Eur J Pharm 1999;9:25-31

11. Chen H, Rhodes J. Schiff base forming drugs: Mechanisms of immune potentiation and therapeutic potential. J Mol Med (Berl) 1996;74:497504.

12. Robert E, Lutz S, Murphey R. Substituted-amino ketones and alcohols related to 4,4'-dichlorobenzoin. J Am Chem Soc 1949;71:478-81.

13. Saleem M, Qazi PH, Rashmi S, Rabiya M, Abid HD, Phali I, et al. Evaluation of anticancer and antimicrobial activities of selected medicinal plants of Kashmir Himalayas, India. Indian J Trad Knowl 2017;16:141-5

14. Pranay J, Shekhar N, Gacrav K. Antimicrobial activity and phytochemical analysis of Eucalptus tereticornis bark and leaf methanolic extracts. Int J Pharm Pharm Sci 2010;4:126-8.

15. Newyork NY, Barnett HL,H unter BB. Illustrated Genera of Imperfect Fungi. Minneapolis: Burgers Company; 1972.

16. Gowrish A, Vagdevi HM, RajashekarH. Phytochemical screening and antimicrobil activity of Leucas marrubioides Desf.root extracts. Int J Pharm Pharm Sci 2016;8:209-12.

17. Horiba N, Maekawa Y, Ito M, Yamamoto T. A pilot study of Japanese 
green tea as a medicament, antibacterial and bactericidal effects. J Endodonitics 1991;17:122-4.

18. Sakanaka S, Kim M, Taniguchi M, Yamamoto T. Antibacterial substances in Japanese green tea extract against Streptococcus mutans a cariogenic bacterium. Agric Biol Chem 1989;53:2307-11.
19. Diker KS, Akan M, Hascelik G, Yurdakok M. The bactericidal activity of tea against Campylobacter jejuni and Campylobacter coli. Lett Appl Microbiol 1991;12:34-5.

20. Opara AA, Ansa MA. The antibacterial activity of tea and coffee on selected organisms. J Medi Lab Sci 1993;3:45-8. 